No. 11(18)

\title{
THE ALLOCATION OF SEATS \\ IN THE EUROPEAN PARLIAMENT AND THE PRINCIPLE \\ OF DEGRESSIVE PROPORTIONALITY
}

\author{
Piotr Peternek, Marek Kośny
}

\begin{abstract}
One of the key issues in the process of preparing for an election to the European Parliament is to determine the number of seats for each country. The Treaty of Lisbon, signed by Member States of the European Union, has obliged the European Parliament to establish rules guaranteeing that the distribution of seats should be done according to, inter alia, the principle of degressive proportionality. The purpose of this paper is to explore how the principle of degressive proportionality is actually implemented, and to propose a compromise - a mathematical solution, guaranteeing that the distribution of seats is consistent with the requirements of the Lisbon Treaty.
\end{abstract}

Keywords: European Parliament, degressive proportionality, optimization.

JEL Classification: C61.

DOI: $10.15611 /$ me.2015.11.09.

\section{Introduction}

The design of most bodies of an international character obliges their members to create a system of methods to take common, usually compromise, decisions. Due to the increasing importance of the European Parliament and the expanding group of its countries - members of the European Union - more attention has been paid to the system of distribution of seats in the European Parliament (see, among others, [Ramirez et al. 2006; Pukelsheim 2007; Łyko et al. 2010; Cegiełka 2011; Cegiełka, Łyko 2014; Misztal 2014]).

A number of the reforms and changes embraced by the European Parliament have ended with the adoption of the Treaty of Lisbon by members of the European Union. Article 9a of this Treaty defines the basic principles which should be followed by the European Parliament in proposals of the

Piotr Peternek, Marek Kośny

Department of Operational Research, Wrocław University of Economics

piotr.peternek@ue.wroc.pl,marek.kosny@ue.wroc.pl 
distribution of seats among states. It postulates that the overall number of Parliament Members shall not exceed 750, and for any given country should fall between 6 and 96. In addition, the number of representatives of each Member State ought to be degressively proportional, and decisions on the allocation of seats among countries are to be taken by the Parliament (see [Official Journal of the European Union 2007]).

The purpose of this paper is to examine how, in fact, the demands set out in the Lisbon Treaty are met (in particular, the principle of degressive proportionality), and to propose a mathematical rule of distribution of votes that fulfills all the requirements defined in this Treaty.

\section{Principle of degressive proportionality}

Analysis of degressive proportionality must be preceded by a description of the situation arising just before the ratification of the Lisbon Treaty. The current number of seats allocated to European Union Member States is the result of a political compromise, a compromise in a situation in which it was not known whether the Lisbon Treaty will be adopted by all the Member States before the parliamentary elections. During the work on the Nice Treaty, there was established the number of seats for each country. The total number of seats was set at 736 . If the Lisbon Treaty had not come into effect, the arrangements of the Treaty of Nice would be applicable. However, if the Lisbon Treaty had been ratified, it was decided - as far as possible - not to worsen the situation of any country in relation to the Nice Treaty. Thus, the difference between the Lisbon Treaty, setting the number of Parliament Members at 750, and 736, resulting from the Nice Treaty, was distributed among countries (see Table 1; further analysis can be found, for example, in [Peternek, Kośny 2011]).

But the new distribution should follow the principle of degressive proportionality, postulated in Article 9a of the Treaty of Lisbon. Required degressivity is not, however, defined in detail. In particular, there exists no precise definition of degression and its strength. A natural way of understanding the notion of degressive proportionality is the requirement of the bigger number of citizens per one seat for countries with a bigger population. This "definition" does not give any additional recommendations. And literature is usually concerned with studying deviations from the proportionality (see, for example, [Haman 2002]).

Let us assume that the principle of degressive proportionality will be understood in the way set out above: for states with a larger population, 
a greater number of citizens per one seat. Thus, if the proportionality is defined as

$$
\frac{n_{i}}{a_{i}}=\text { const, }
$$

where $a_{i}$ - number of seats and $n_{i}$ - number of voters (citizens), then degressive proportionality would denote a situation in which

where $n_{i} \leq n_{i+1}$ and $a_{i} \leq a_{i+1}$.

$$
\frac{n_{i}}{a_{i}} \leq \frac{n_{i+1}}{a_{i+1}}
$$

Table 1 and Figure 1 present the ratios of the number of citizens per one seat. It is easy to note that according to the provisions of the Nice Treaty, the principle of degressive proportionality is not obeyed - but this prerogative had not been defined yet. However, the requirement of degressive proportionality should be respected after ratification of the Lisbon Treaty. And this rule is broken in the case of Italy.

Table 1. Number of seats, population and number of citizens per one seat

\begin{tabular}{|c|c|c|c|c|c|c|c|c|c|c|c|}
\hline \multirow{2}{*}{$\begin{array}{l}\text { Coun- } \\
\text { try }\end{array}$} & \multirow{2}{*}{$\begin{array}{l}\text { The } \\
\text { Nice } \\
\text { Treaty }\end{array}$} & \multirow{2}{*}{$\begin{array}{l}\text { The } \\
\text { Lisbon } \\
\text { Treaty }\end{array}$} & \multirow{2}{*}{$\begin{array}{l}\text { Popu- } \\
\text { lation }\end{array}$} & \multicolumn{2}{|c|}{ Population per seat } & \multirow{2}{*}{$\begin{array}{c}\text { Coun- } \\
\text { try }\end{array}$} & \multirow{2}{*}{$\begin{array}{l}\text { The } \\
\text { Nice } \\
\text { Treaty }\end{array}$} & \multirow{2}{*}{$\begin{array}{l}\text { The } \\
\text { Lisbon } \\
\text { Treaty }\end{array}$} & \multirow{2}{*}{$\begin{array}{l}\text { Popu- } \\
\text { lation }\end{array}$} & \multicolumn{2}{|c|}{ Population per seat } \\
\hline & & & & $\begin{array}{l}\text { The } \\
\text { Nice } \\
\text { Treaty }\end{array}$ & $\begin{array}{l}\text { The } \\
\text { Lisbon } \\
\text { Treaty }\end{array}$ & & & & & $\begin{array}{c}\text { The } \\
\text { Nice } \\
\text { Treaty }\end{array}$ & $\begin{array}{c}\text { The } \\
\text { Lisbon } \\
\text { Treaty }\end{array}$ \\
\hline MT & 5 & 6 & 0.4 & 80000 & 66667 & $\mathrm{HU}$ & 22 & 22 & 10.1 & 459091 & 459091 \\
\hline LU & 6 & 6 & 0.5 & 83333 & 83333 & $\mathrm{CZ}$ & 22 & 22 & 10.3 & 468182 & 468182 \\
\hline $\mathrm{CY}$ & 6 & 6 & 0.8 & 133333 & 133333 & $\mathrm{BE}$ & 22 & 22 & 10.6 & 481818 & 481818 \\
\hline $\mathrm{EE}$ & 6 & 6 & 1.3 & 216667 & 216667 & PT & 22 & 22 & 10.6 & 481818 & 481818 \\
\hline SI & 7 & 8 & 2.0 & 285714 & 250000 & EL & 22 & 22 & 11.2 & 509091 & 509091 \\
\hline LV & 8 & 9 & 2.3 & 287500 & 255556 & NL & 25 & 26 & 16.3 & 652000 & 626923 \\
\hline LT & 12 & 12 & 3.4 & 283333 & 283333 & RO & 33 & 33 & 21.6 & 654546 & 654546 \\
\hline IE & 12 & 12 & 4.3 & 358333 & 358333 & PL & 50 & 51 & 38.2 & 764000 & 749020 \\
\hline FI & 13 & 13 & 5.3 & 407692 & 407692 & ES & 50 & 54 & 44.5 & 890000 & 824074 \\
\hline DK & 13 & 13 & 5.4 & 415385 & 415385 & IT & 72 & 73 & 59.1 & 820833 & 809589 \\
\hline SK & 13 & 13 & 5.4 & 415385 & 415385 & UK & 72 & 73 & 60.9 & 845833 & 834247 \\
\hline BG & 17 & 18 & 7.7 & 452941 & 427778 & FR & 72 & 74 & 63.4 & 880556 & 856757 \\
\hline AT & 17 & 19 & 8.3 & 488235 & 436842 & $\mathrm{DE}$ & 99 & 96 & 82.3 & 831313 & 857292 \\
\hline $\mathrm{SE}$ & 18 & 20 & 9.0 & 500000 & 450000 & & & & & & \\
\hline
\end{tabular}
as determined by the Treaty of Nice and the Treaty of Lisbon

Source: own elaboration. 


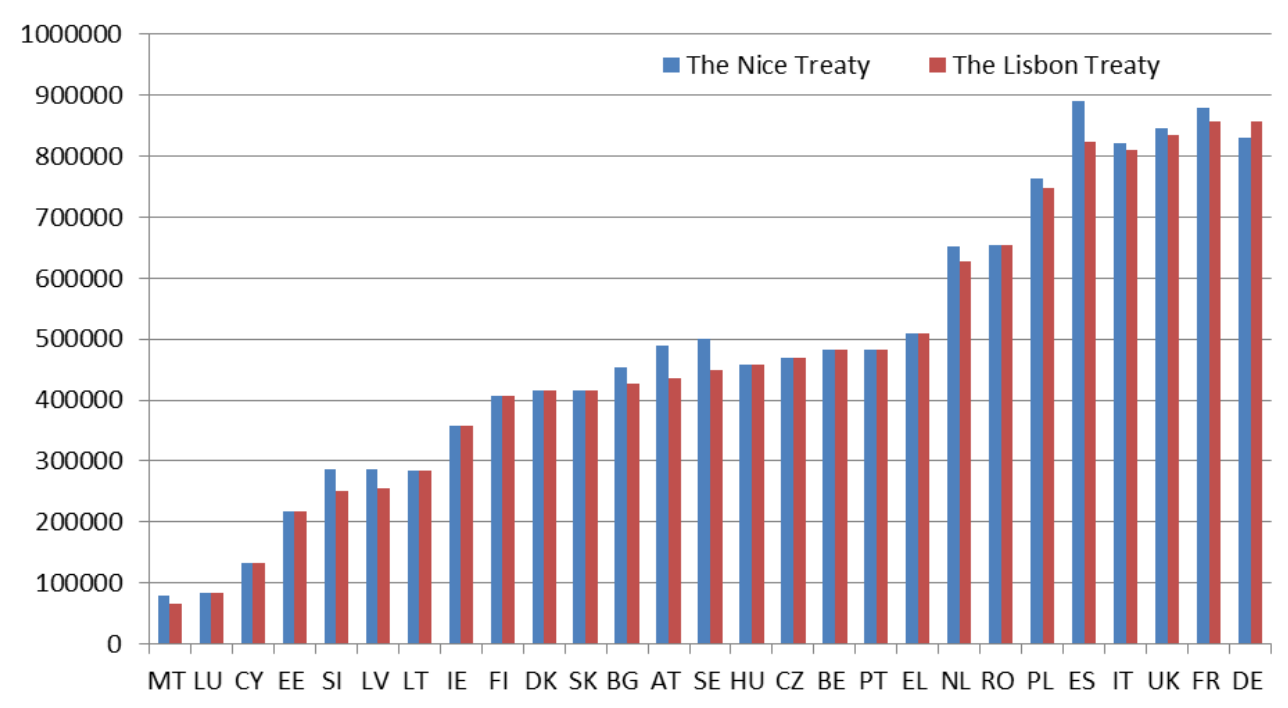

Fig. 1. Number of citizens per one seat as determined by the Treaty of Nice and the Treaty of Lisbon

Source: own elaboration.

Violation of the principle of degressive proportionality is in conflict with the provisions of the Treaty of Lisbon. It is therefore reasonable to search for another, non-political, compromise which can ensure the fulfillment of the postulated rules.

\section{A quest for alternative methods of the allocation of seats}

This paper presents two types of approaches to the distribution of seats. The first one is a heuristic approach. In the first step a distribution of votes is proposed according to an algorithm which takes into account the requirements concerning the minimum and maximum number of seats. The fulfillment of the principle of degressive proportionality is examined in the second step. The second approach is based on the optimization model, in which all the rules laid down in the Lisbon Treaty are represented as constraints or an objective function. In this case the solution - if it exists satisfies all the requirements.

The first of the analyzed methods was considered in the paper by Peternek and Kośny [2011]. This method attributes 6 seats to each country, and the remaining 582 votes are allocated in proportion to the population (rounding to the nearest integer). However, such a simple method does not 
produce an acceptable solution - there is one country (Germany), for which the number of seats exceeds 96. In addition, the result does not satisfy degressive proportionality (see Table 2 and Figure 2).

Table 2. Number of seats and number of citizens per one seat according to the first method

\begin{tabular}{|c|c|c|c|c|c|}
\hline Country & $\begin{array}{c}\text { Number } \\
\text { of seats }\end{array}$ & $\begin{array}{c}\text { Population } \\
\text { per seat }\end{array}$ & Country & $\begin{array}{c}\text { Number } \\
\text { of seats }\end{array}$ & $\begin{array}{c}\text { Population } \\
\text { per seat }\end{array}$ \\
\hline MT & 6 & 70897 & SE & 17 & 567345 \\
\hline LU & 6 & 91613 & HU & 17 & 581022 \\
\hline CY & 6 & 143000 & CZ & 17 & 613371 \\
\hline EE & 7 & 187974 & PT & 18 & 584023 \\
\hline SI & 8 & 250184 & BE & 18 & 610699 \\
\hline LV & 8 & 257636 & EL & 18 & 622444 \\
\hline LT & 9 & 327052 & NL & 25 & 673172 \\
\hline CR & 10 & 424681 & RO & 28 & 712404 \\
\hline IE & 11 & 418682 & PL & 49 & 775875 \\
\hline FI & 12 & 451329 & ES & 59 & 788342 \\
\hline SK & 12 & 454273 & IT & 75 & 810436 \\
\hline DK & 12 & 468936 & UK & 79 & 814029 \\
\hline BG & 14 & 517548 & FR & 81 & 812785 \\
\hline AT & 15 & 567126 & DE & 98 & 824158 \\
\hline
\end{tabular}

Source: own elaboration.

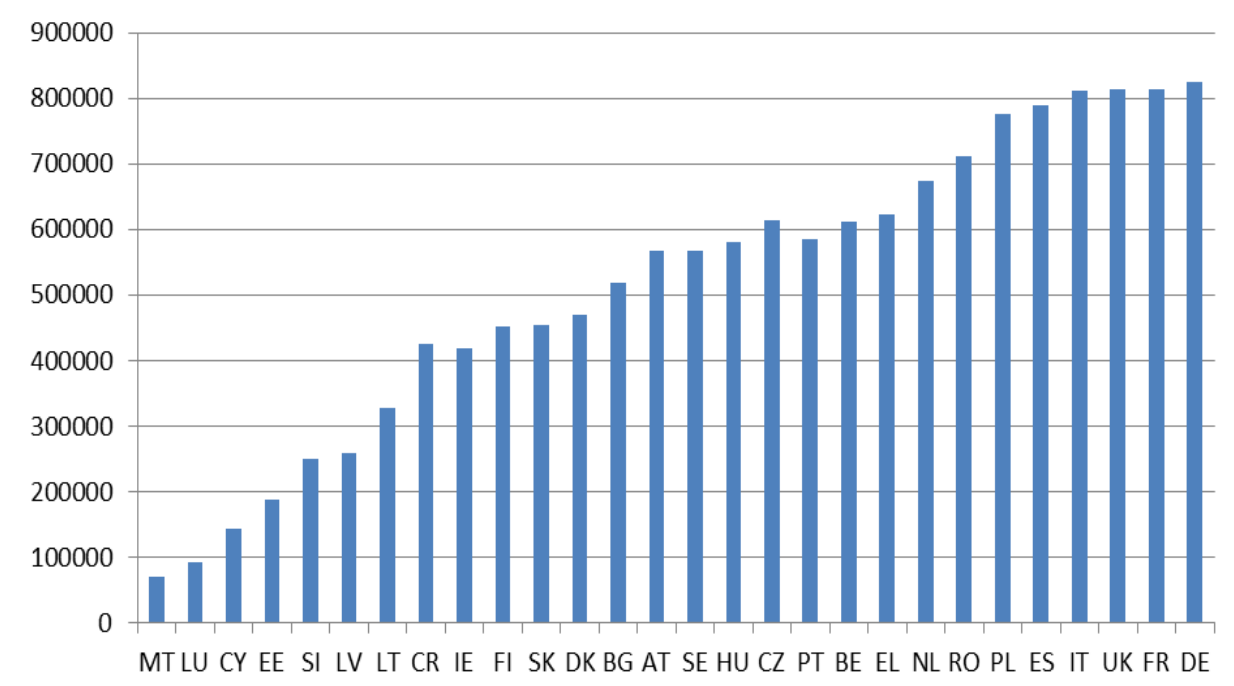

Fig. 2. Number of citizens per one seat according to the first method

Source: own elaboration. 
Table 3. Number of seats and number of citizens per one seat according to the square root method

\begin{tabular}{|c|c|c|c|c|c|}
\hline Country & $\begin{array}{c}\text { Number } \\
\text { of seats }\end{array}$ & Population/Seat & Country & $\begin{array}{c}\text { Number } \\
\text { of seats }\end{array}$ & Population/Seat \\
\hline MT & 9 & 47265 & SE & 24 & 401869 \\
\hline LU & 10 & 54968 & HU & 24 & 411557 \\
\hline CY & 11 & 78000 & CZ & 25 & 417092 \\
\hline EE & 12 & 109652 & PT & 25 & 420497 \\
\hline SI & 14 & 142962 & BE & 25 & 439704 \\
\hline LV & 14 & 147220 & EL & 25 & 448160 \\
\hline LT & 16 & 183967 & NL & 30 & 560976 \\
\hline CR & 18 & 235934 & RO & 32 & 623354 \\
\hline IE & 18 & 255861 & PL & 42 & 905187 \\
\hline FI & 19 & 285050 & ES & 46 & 1011135 \\
\hline SK & 19 & 286909 & IT & 51 & 1191817 \\
\hline DK & 19 & 296170 & UK & 53 & 1213363 \\
\hline BG & 21 & 345032 & FR & 53 & 1242181 \\
\hline AT & 23 & 369865 & DE & 58 & 1392542 \\
\hline
\end{tabular}

Source: own elaboration.

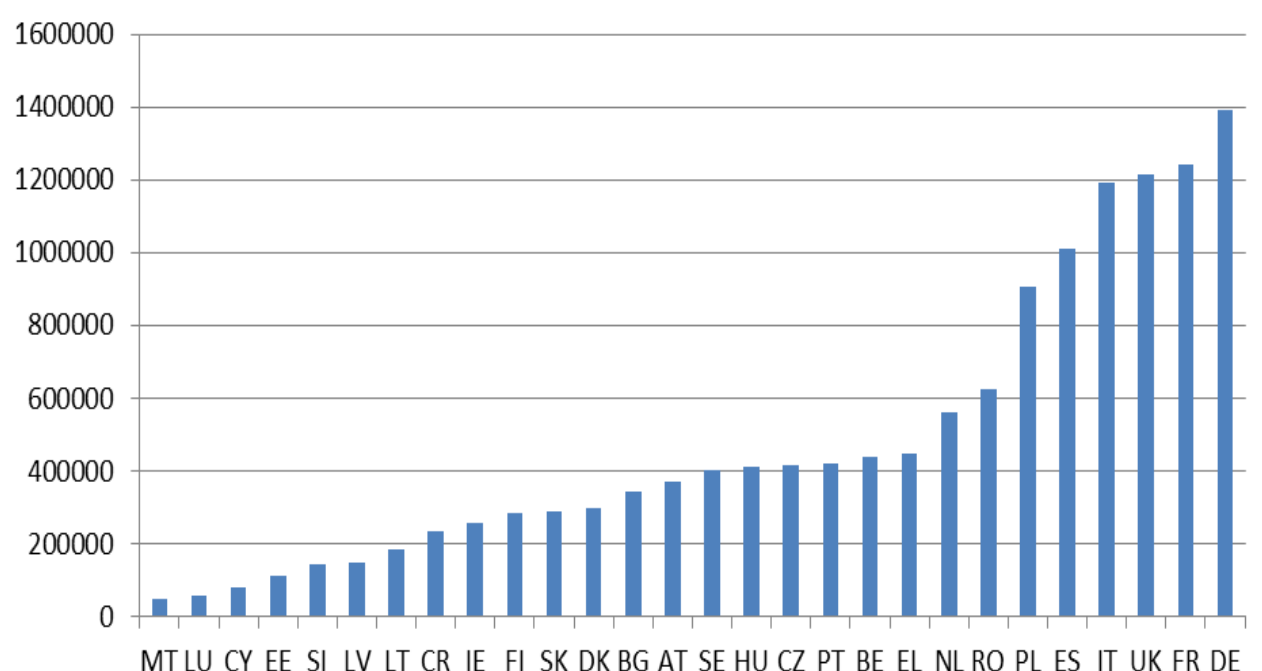

Fig. 3. Number of citizens per one seat according to the square root method

Source: own elaboration. 
In the second heuristic method, aimed at determining the number of seats, the population size is replaced by its square root, and the procedure of distributing seats is the same as described above. The results are presented in Table 3 and Figure 3. This method gives better results - all the demands are met. It is worth noting, however, that the increase in the number of seats is much slower. This results in a significant flattening of the distribution of the number of seats.

Table 4. Number of seats and number of citizens per one seat according to the linear transformation method

\begin{tabular}{|c|c|c|c|c|c|}
\hline Country & $\begin{array}{c}\text { Number } \\
\text { of seats }\end{array}$ & $\begin{array}{c}\text { Population } \\
\text { per seat }\end{array}$ & Country & $\begin{array}{c}\text { Number } \\
\text { of seats }\end{array}$ & $\begin{array}{c}\text { Population } \\
\text { per seat }\end{array}$ \\
\hline MT & 6 & 70897 & SE & 16 & 602804 \\
\hline LU & 6 & 91613 & HU & 16 & 617335 \\
\hline CY & 6 & 143000 & CZ & 17 & 613371 \\
\hline EE & 6 & 219303 & PT & 17 & 618378 \\
\hline SI & 7 & 285924 & BE & 17 & 646623 \\
\hline LV & 7 & 294441 & EL & 18 & 622444 \\
\hline LT & 8 & 367934 & NL & 24 & 701220 \\
\hline CR & 10 & 424681 & RO & 27 & 738789 \\
\hline IE & 10 & 460550 & PL & 48 & 792039 \\
\hline FI & 11 & 492359 & ES & 57 & 816004 \\
\hline SK & 11 & 495570 & IT & 73 & 832639 \\
\hline DK & 11 & 511567 & UK & 77 & 835172 \\
\hline BG & 13 & 557360 & FR & 79 & 833362 \\
\hline AT & 15 & 567126 & DE & 96 & 841328 \\
\hline
\end{tabular}

Source: own elaboration. 


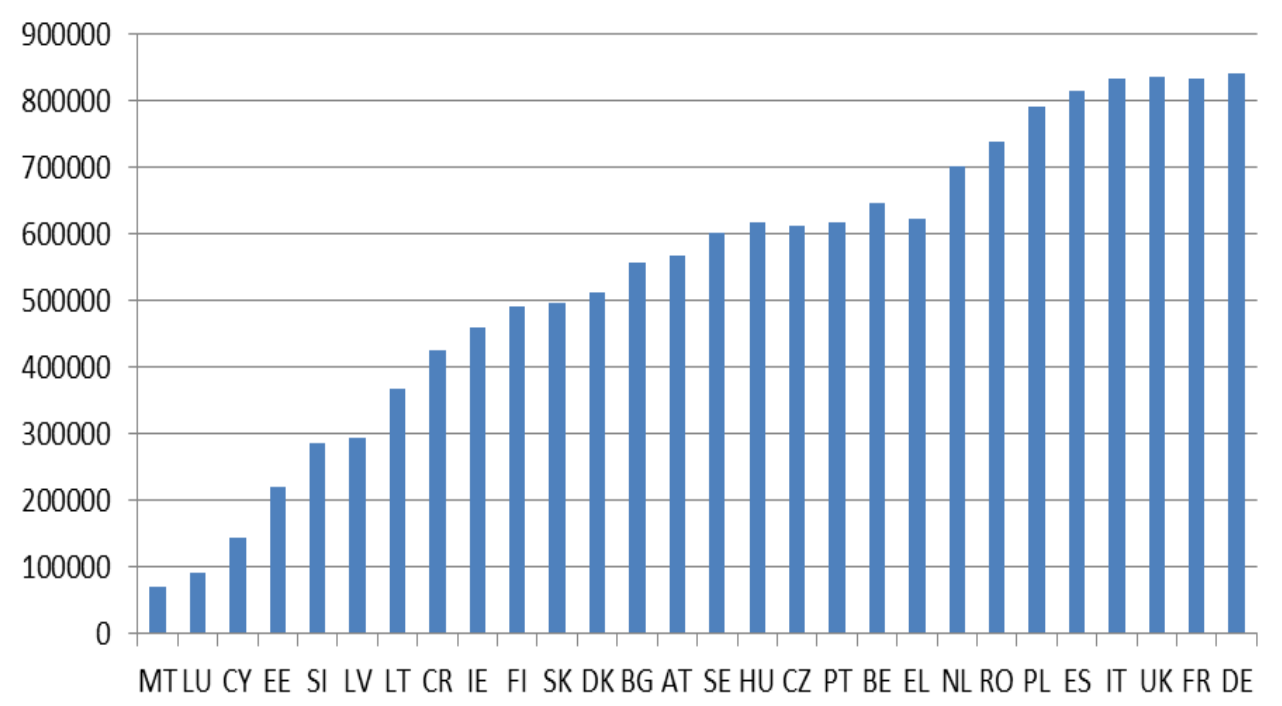

Fig. 4. Number of citizens per one seat according to the linear transformation method Source: own elaboration.

One disadvantage, which is the flattening of the resulting distribution of the number of seats, could be removed by a linear transformation adopted in the third method. In this method, the overall number of seats for a given country is, as previously, the sum of the transformed population size and 6 seats, as guaranteed by the Lisbon Treaty. In this method, however, population size is transformed by a linear function of the form $f\left(n_{i}\right)=0,00000112 n_{i}-0.4765$ where $n_{i}$ denotes the population of a country. Parameters of this linear transformation were calculated to let this function pass through the points $(425384,0)$ and $(80767463,90)$ where the first coordinate reflects population size and the second - the number of seats above 6 . This means that the smallest country (Malta), would get 6 seats and the biggest (Germany) - 96 seats. This solution actually guarantees a considerably higher variation in the number of seats (see Table 4), but in two cases (Greece and Hungary, see Figure 4) does not satisfy the principle of degressive proportionality.

Thus, out of the three proposed methods, only the use of a square root transformation guaranteed a degressive proportionality. This procedure, however, has certain disadvantages associated with a significantly flattened distribution of the number of seats, which significantly weakens the relative position of large countries. 


\section{Determining number of seats - model approach}

The methods of obtaining the distribution of seats presented in the previous section, do not guarantee that all the assumptions defined in the Treaty of Lisbon are met. Therefore, it becomes necessary to propose a method that would give a result which meets all the existing requirements and that would enable the fulfillment of other potentially possible postulates. Such a general formulation is possible for an optimization model. A key issue for such a model is to define the objective function. The paper proposes the following approach. We assumed that for the smallest country the number of seats should be equal to the minimum value declared in the Treaty, and the number of seats for the largest country should be equal to the maximum number of seats. These two points, determined by the number of inhabitants of a given country and its number of seats, allow for the approximation of the function passing through them. The objective function should minimize the squared differences between the number of seats obtained from the model and the "theoretical" number of seats, resulting from this function. The last issue is the choice of a type of this function. In the paper two types - linear and exponential - will be analyzed:
1) $\hat{x}_{i}=a n_{i}+b$
$\left(a=1,12 \cdot 10^{-6} ; b=5,52\right)$,
2) $\hat{x}_{i}=a \exp \left(b n_{i}\right) \quad\left(a=5.912 ; b=3,45 \cdot 10^{-8}\right)$.

The model is defined as follows:

Objective function: $\sum_{i=1}^{28}\left(x_{i}-\hat{x}_{i}\right)^{2} \rightarrow \min$.

Subject to:

(1) $x_{i} \leq x_{i+1}$ for $i=1, \ldots, 27$,

(2) $\frac{n_{i}}{x_{i}} \leq \frac{n_{i+1}}{x_{i+1}}$ for $i=1, \ldots, 27$,

(3) $736 \leq \sum_{i=1}^{28} x_{i} \leq 750$,

(4) $x_{1}=6$,

(5) $x_{28}=96$,

(6) $x_{i} \in \mathbf{C}$,

where $x_{i}$ denotes the number of seats for the $i$-th country (countries are given in ascending order according to their population size). 
Solving this model requires ranking countries with respect to their population size, such as $n_{i} \leq n_{i+1}$. The first constraint ensures that each country will have a number of seats no less than any smaller country. The second constraint defines the degressive proportionality. The third one ensures that total number of seats does not exceed 750, the value established in the Lisbon Treaty. The lower limit is set at 736 - the number of seats before the reform. The next two constraints concern the minimum and maximum number of seats for, respectively, the smallest and the largest country. The last one requires that number of allocated seats is an integer.

The results of solving such models are shown in Table 5 and Table 6 . Population per one seat is shown in these tables and in Figure 5.

Table 5. Number of seats and number of citizens per one seat according to the model with a linear function

\begin{tabular}{|c|c|c|c|c|c|}
\hline Country & $\begin{array}{c}\text { Number } \\
\text { of seats }\end{array}$ & $\begin{array}{c}\text { Population } \\
\text { per seat }\end{array}$ & Country & $\begin{array}{c}\text { Number } \\
\text { of seats }\end{array}$ & $\begin{array}{c}\text { Population } \\
\text { per seat }\end{array}$ \\
\hline MT & 6 & 70897 & SE & 18 & 535826 \\
\hline LU & 7 & 78526 & HU & 18 & 548743 \\
\hline CY & 7 & 122571 & CZ & 18 & 579295 \\
\hline EE & 8 & 164477 & PT & 18 & 584023 \\
\hline SI & 9 & 222385 & BE & 18 & 610699 \\
\hline LV & 9 & 229009 & EL & 18 & 622444 \\
\hline LT & 10 & 294347 & NL & 25 & 673172 \\
\hline CR & 11 & 386074 & RO & 29 & 687838 \\
\hline IE & 11 & 418682 & PL & 48 & 792039 \\
\hline FI & 12 & 451329 & ES & 57 & 816004 \\
\hline SK & 12 & 454273 & IT & 74 & 821387 \\
\hline DK & 12 & 468936 & UK & 78 & 824465 \\
\hline BG & 15 & 483045 & FR & 79 & 833369 \\
\hline AT & 16 & 531681 & DE & 96 & 841328 \\
\hline
\end{tabular}

Source: own elaboration. 
Table 6. Number of seats and number of citizens per one seat according to the model with an exponential function

\begin{tabular}{|c|c|c|c|c|c|}
\hline Country & $\begin{array}{c}\text { Number } \\
\text { of seats }\end{array}$ & $\begin{array}{c}\text { Population } \\
\text { per seat }\end{array}$ & Country & $\begin{array}{c}\text { Number } \\
\text { of seats }\end{array}$ & $\begin{array}{c}\text { Population } \\
\text { per seat }\end{array}$ \\
\hline MT & 6 & 70897 & SE & 15 & 642991 \\
\hline LU & 6 & 91613 & HU & 15 & 658491 \\
\hline CY & 6 & 143000 & CZ & 15 & 695153 \\
\hline EE & 6 & 219303 & PT & 15 & 700828 \\
\hline SI & 6 & 333578 & BE & 15 & 732839 \\
\hline LV & 6 & 343514 & EL & 15 & 746933 \\
\hline LT & 8 & 367934 & NL & 22 & 764968 \\
\hline CR & 11 & 386074 & RO & 26 & 767204 \\
\hline IE & 11 & 418682 & PL & 49 & 775875 \\
\hline FI & 12 & 451329 & ES & 59 & 788342 \\
\hline SK & 12 & 454273 & IT & 76 & 799772 \\
\hline DK & 12 & 468936 & UK & 79 & 814029 \\
\hline BG & 12 & 603806 & FR & 79 & 833362 \\
\hline AT & 14 & 607635 & DE & 96 & 841328 \\
\hline
\end{tabular}

Source: own elaboration.

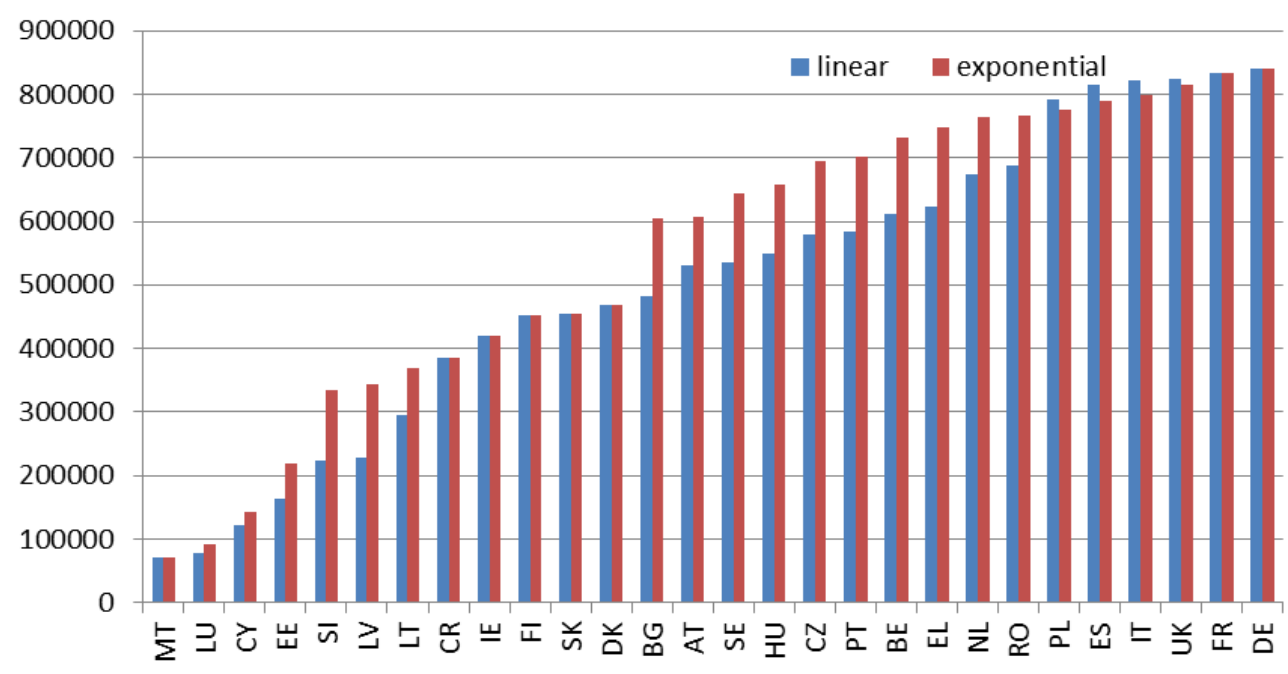

Fig. 5. Number of citizens per one seat according to the models with a linear and exponential functions

Source: own elaboration. 
Analysis of Figure 5 suggest, however, that in order to better reflect the idea of degressive proportionality, the population per one seat should be examined instead of the number of seats. Hence the objective function in the new model was changed to take this into account. Therefore we minimize the sum of the squares of the difference between the population falling per one seat and the theoretical function. The conditions guaranteeing the minimum (6) and maximum (96) number of seats for the smallest and the largest country still hold. The modified model takes the following form:

Objective function:

$$
\sum_{i=1}^{28}\left(\frac{n_{i}}{x_{i}}-\frac{\hat{n}_{i}}{x_{i}}\right)^{2} \rightarrow \min
$$

where

$$
\frac{\hat{n}_{i}}{x_{i}}=a \exp \left(b n_{i}\right) \text { and } a=69974,8 ; b=3 \cdot 10^{-8} .
$$

Subject to:

(1) $x_{i} \leq x_{i+1}$ for $i=1, \ldots, 28$,

(2) $\frac{n_{i}}{x_{i}} \leq \frac{n_{i+1}}{x_{i+1}}$ for $i=1, \ldots, 28$,

(3) $736 \leq \sum_{i=1}^{28} x_{i} \leq 750$,

(4) $x_{1}=6$,

(5) $x_{28}=96$,

(6) $x_{i} \in \mathbf{C}$.

where $x_{i}$ denotes the number of seats for the $i$-th country (countries are given in ascending order according to their population size).

The results obtained for this model can be found in Table 7 and corresponding ratios - in Table 7 and Figure 6. 
Table 7. Number of seats and number of citizens per one seat according to the model with an exponential function for quotient

\begin{tabular}{|c|c|c|c|c|c|}
\hline Country & $\begin{array}{c}\text { Number } \\
\text { of seats }\end{array}$ & $\begin{array}{c}\text { Population } \\
\text { per seat }\end{array}$ & Country & $\begin{array}{c}\text { Number } \\
\text { of seats }\end{array}$ & $\begin{array}{c}\text { Population } \\
\text { per seat }\end{array}$ \\
\hline MT & 6 & 70897 & SE & 16 & 602804 \\
\hline LU & 7 & 78526 & HU & 16 & 617335 \\
\hline CY & 10 & 85800 & CZ & 16 & 651706 \\
\hline EE & 13 & 101219 & PT & 16 & 657026 \\
\hline SI & 13 & 153959 & BE & 16 & 687034 \\
\hline LV & 13 & 158545 & EL & 16 & 700250 \\
\hline LT & 13 & 226421 & NL & 22 & 764968 \\
\hline CR & 14 & 303344 & RO & 26 & 767204 \\
\hline IE & 14 & 328964 & PL & 47 & 808891 \\
\hline FI & 14 & 386854 & ES & 57 & 816004 \\
\hline SK & 14 & 389376 & IT & 74 & 821387 \\
\hline DK & 14 & 401945 & UK & 78 & 824465 \\
\hline BG & 14 & 517548 & FR & 79 & 833362 \\
\hline AT & 16 & 531681 & DE & 96 & 841323 \\
\hline
\end{tabular}

Source: own elaboration.

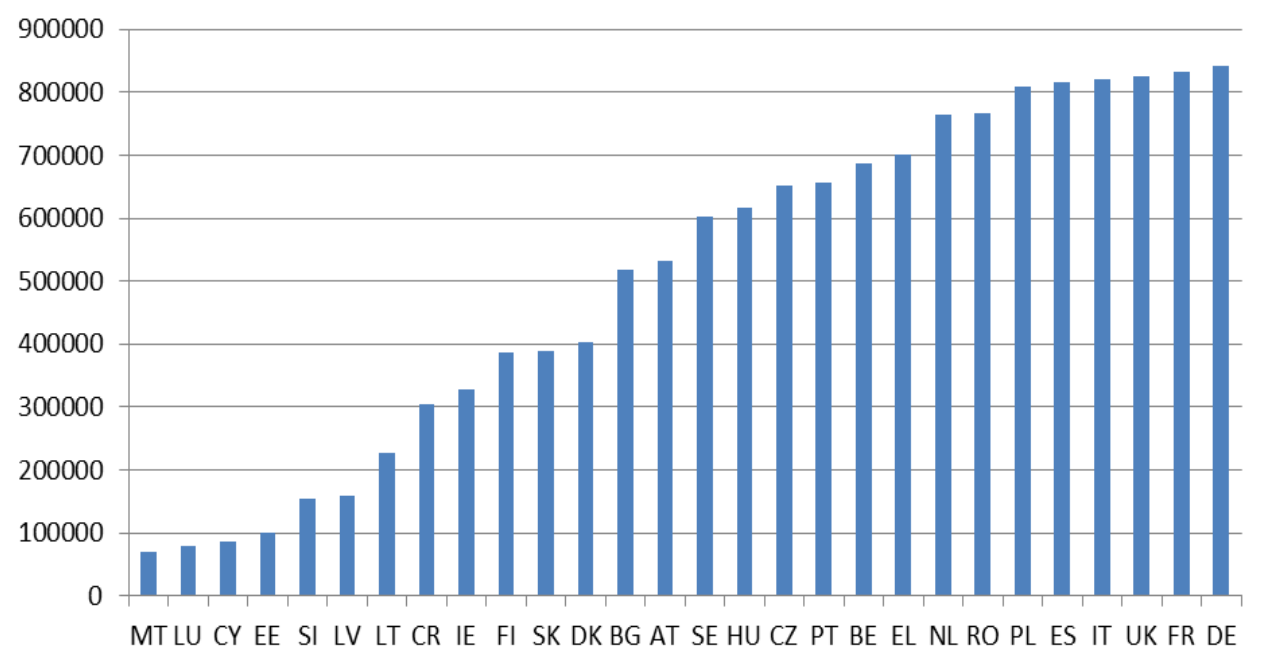

Fig. 6. Number of citizens per one seat according to the model with an exponential function for quotient

Source: own elaboration. 


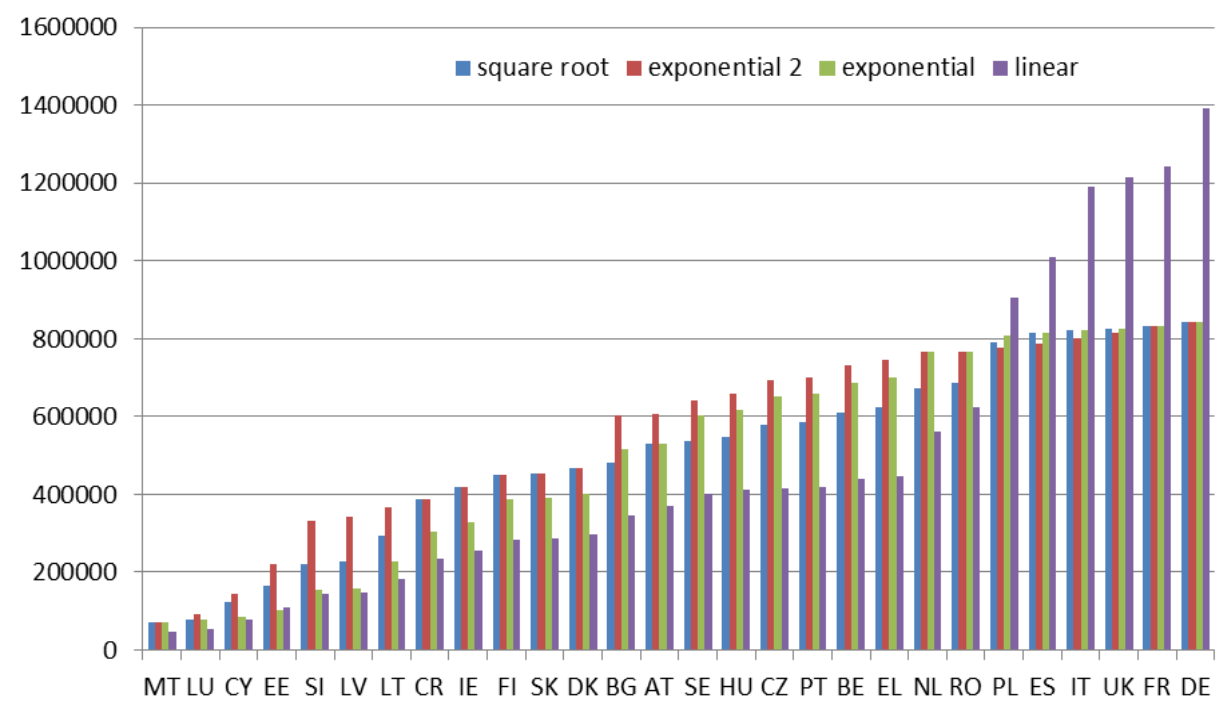

Fig. 7. Comparison of numbers of citizens per one seat according to the analyzed methods

Source: own elaboration.

\section{Conclusion}

The allocation of the number of seats proposed by the European Parliament is a result of a political compromise which does not meet - as shown in the paper - the requirements of the Treaty of Lisbon. Therefore it becomes necessary to construct a method that allows for the allocation of seats in line with the demands contained in various treaties - both current and future. The paper presents several options. Quotients of the population and the number of seats for the analyzed methods which meet the assumptions set out in the Treaty of Lisbon, are shown in Figure 7. The authors would like to draw particular attention to the model approach because it allows for the fulfillment of all hitherto existing requirements and is open to new possible recommendations.

\section{References}

Cegiełka K. (2011). Degressive proportionality in the European Parliament. Mathematical Economics 7(14). Pp. 31-38.

Cegiełka K., Łyko J. (2014). Application of Hamilton's and divisor methods to degressively proportional allocation functions. Procedia - Social and Behavioral Sciences 110. Pp. 103-112. 
Haman J. (2002). Podziat mandatów pomiędzy okręgi wyborcze w świetle teorii sprawiedliwego podziału dóbr. Przegląd Sejmowy 1(48). Parliament Publishing House. Warszawa (in Polish).

Łyko J., Cegiełka K., Dniestrzański P., Misztal A. (2010). Demographic changes and principles of the fair division. International Journal of Social Sciences and Humanity Studies 2(2) (online).

Misztal A. (2014). Degresywna proporcjonalność a kształtowanie składu Parlamentu Europejskiego. Wroclaw University of Economics Publishing House. Wrocław.

Official Journal of the European Union (2007). C 306. Volume 50. 17.12.2007.

Peternek P., Kośny M. (2011). Układ sił w Parlamencie Europejskim a rozdział mandatów pomiędzy kraje członkowskie Unii Europejskiej. In: J. Gajda, R. Jadczak (ed.). Optymalizacja, klasyfikacja, logistyka. Lodz University Publishing House. Łódź. Pp. 142-158 (in Polish).

Pukelsheim F. (2007). Putting Citizens First. Representation and Power in the European Union. In: Distribution of Power and Voting Procedures in the European Union. Proceedings of a Natolin International Workshop on Distribution of Power and Voting Procedures in the European Union. Warszawa.

Ramirez V., Polomares A., Marquez M. (2006). Degressively Proportional Methods for the Allotment of the European Seats Amongst the EU Member States. In: B. Simeone, F. Pukelsheim (eds.). Mathematics and Democracy. Springer Verlag. Berlin. Pp. 205-220. 